\title{
ANTIMICROBIAL DRUGS, PESTICIDES AND PAHs IN HONEY
}

\author{
Jelena Petrović ${ }^{1 *}$, Radomir Ratajac ${ }^{1}$, Jelena Vranešević ${ }^{1}$, Igor Stojanov ${ }^{1}$, \\ Jasna Prodanov Radulović1, Brankica Kartalović ${ }^{1}$
}

${ }^{1}$ Scientific Veterinary Institute „Novi Sad“, Novi Sad, Republic of Serbia

\section{Abstract}

Honey is a very popular food that is often consumed by immunocompromised people, so it is crucial that it is safe. The safety of honey is related to numerous hazards, especially the chemical ones like residues of sulfonamides, lindane and polycyclic aromatic hydrocarbons (PAHs). Honey from our country contains high concentrations of banned antimicrobial substances such as sulfonamides (3.9\% of samples). The frequent presence of lindane in honey is not unexpected considering the fact that this pesticide is present in the soil, plants and animals from Serbia. PAHs as a relatively unexplored chemical hazard in honey proved to be widespread in the honey from Serbia - even 6.6\% of honey samples contains toxic concentrations of these compounds. The control of chemical hazards and the production of safe honey in Serbia could be improved by implementing better measures to prevent illegal use of antimicrobial drugs, pollution control and further research in the field of risk assessment.

Key words: honey, sulfonamides, lindane, PAHs, food safety

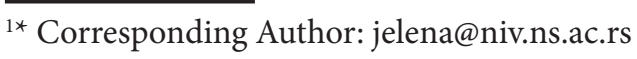




\title{
ANTIMIKROBNI LEKOVI, PESTICIDI I PAH U MEDU
}

\author{
Jelena Petrović1 ${ }^{*}$, Radomir Ratajac ${ }^{1}$, Jelena Vranešević ${ }^{1}$, \\ Igor Stojanov ${ }^{1}$, Jasna Prodanov Radulović ${ }^{1}$, Brankica Kartalović ${ }^{1}$ \\ ${ }^{1}$ Naučni institut za veterinarstvo „Novi Sad“, Novi Sad, Republika Srbija
}

\section{Kratak sadržaj}

Med je vrlo popularna namirnica koju često konzumiraju imunokompromitovane osobe, stoga je njegova bezbednost od izuzetnog značaja. Bezbednost meda je određena brojnim hazardima među hemijskim se ističu rezidue sulfonamida, lindana i policikličnih aromatičnih ugljovodonika (PAH). Med sa prostora naše zemlje sadrži visoke koncentracije zabranjenih supstanci kao što su sulfonamidi (3.9\% uzoraka). Često prisustvo lindana u medu nije neočekivano s obzirom da je ovaj perzistentni pesticid prisutan $\mathrm{u}$ zemljištu, biljkama i životinjama Srbije. Policiklični aromatični ugljovodonici kao relativno ne proučavani hemijski hazardi meda su se pokazali kao vrlo prisutni u medu iz Srbije, čak 6.6\% uzoraka sadrži toksične koncentracije ovih jedinjenja. Unapređenje kontrole hemijskih hazarda i proizvodnja bezbednog meda u Srbiji bi se postigli efikasnijom primenom mera za sprečavanje ilegalne upotrebe antimikrobnih lekova, kontrolom zagađenja i daljim istraživanjima u oblasti procene rizika.

Ključne reči: med, sulfonamidi, lindan, $\mathrm{PAH}$, bezbednost hrane

\section{INTRODUCTION}

Honey is the most important product of honey bees. It has been used in the diet since prehistoric times, mainly because of its pleasant taste and nutritional properties. Honey is often consumed by immunocompromised people because it's medical effect. Honey has antioxidant, bioactive, antimicrobial, anti-inflammatory, antithrombotic and antiallergic effects, depending on the type (Cook and Sammon, 1996). Since honey is often consumed by vulnerable population, the standards set for its safety are very strict (Wei et al., 2012). Hazards, i.e. dangers to the health of consumers, which are most commonly related to the safety of honey, are residues of veterinary medical products and pesticides. In our recent research, it has been found that there is a risk associated with the presence of polycyclic aromatic hydrocarbons (PAHs) in honey. 
Bees collect nectar in a radius of 3 to $10 \mathrm{~km}$ around the hives, so bees, pollen and honey are considered bioindicators of environmental pollution, especially when it comes to radionuclides, PAHs and pesticides. (Bogdanov 2006; Babić et al., 2017; Petrović et al., 2019).

When assessing the importance of certain chemical hazards for the safety of honey, it is necessary to keep in mind the fact that honey differs greatly from other foods of animal origin. When some of the chemical hazards enter the body of mammals or birds, it undergoes active metabolism, where chemical substances are transformed into metabolites which are then deposited in the tissues of the animal and more or less excreted from the body through urine, feces, milk, etc. Chemical hazards usually reach the nectar or sugar syrup that bees feed on. Bees then secrete enzymes that break down the nectar into simple sugars: glucose, fructose and sucrose and deposit the nectar in the honeycombs, and over time the water evaporates and thick syrup is formed - honey (Solomon et al., 2006). If veterinary drugs, pesticides, PAHs are present in nectar or sugar syrup, they are transported in unchanged form in honey (Reybroeck et al., 2012). Decomposition of labile chemical compounds can occur in honey. However, sulfonamides, PAHs and lindane are very stable, so not only does the concentration not decrease, but due to water evaporation, the initial concentration increases, which does not change until the end of honey storage. Therefore, once contaminated honey remains contaminated over a long period of time and can pose a risk to the health of consumers, particularly immunocompromised population.

The main goal of this paper is to present the results of our research on the presence of sulfonamide residues, lindane and PAHs in honey produced in our country and to point out the importance of these chemical hazards for the safety of our honey.

\section{SULFONAMIDES}

In the past, the use of sulfonamides was allowed in beekeeping for the treatment of American bee brood plague (Plavša et al. 2008). However, the appearance of residues of these drugs in honey produced by treated bees has led to a ban on the use of sulfonamides in the treatment of bee diseases in the USA (Barganska et al, 2011). If food with sulfonamide residues is consumed, allergic reactions may occur (Maroubo et al., 2021). In our country, like in most EU countries, it is not allowed to treat bees with antimicrobial drugs (Kartalović et al., 2020). Therefore, any occurrence of sulfonamide residues in honey is a result of their intentional and illegal use for prevention and treatment of bee diseases. 
Examination of honey samples from Serbia revealed the presence of sulfonamides in $3.9 \%$ of samples (Table 1). The residues of sulfadiazine (3.9\%) were most commonly found, followed by sulfamethoxazole (1.7\%) and sulphapyridine (1.1\%). Illegal substances are common in flower $28.6 \%$, sunflower $10.0 \%$, meadow 3.8\% and acacia honey (1.7\%) (Kartalović et al., 2020). Due to the ban on the use of sulfonamides in beekeeping, all the samples shown in Table 1 are not safe for human consumption. Three honey samples (sunflower, meadow and acacia) had extremely high total content of sulfonamide residues - it was even higher than the maximum residue limits (MRL) of sulfonamide residues for any food in the EU.

Table 1: Honey samples with quantified residue (ng/g) (Kartalović et al., 2020)

\begin{tabular}{lllll}
\hline \multicolumn{1}{c}{ sample } & sulfadiazine & sulfamethizole & sulfopyridine & sum \\
\hline sunflower & 11 & 370 & $<$ LOQ & 381 \\
meadow & $<$ LOQ & 59 & $<$ LOQ & 59 \\
meadow & 7.8 & $<$ LOQ & $<$ LOQ & 7.8 \\
meadow & 97 & $<$ LOQ & 9.1 & 106.1 \\
flower & 9.2 & $<\mathrm{LOQ}$ & 8.2 & 17.4 \\
acacia & $<\mathrm{LOQ}$ & 208 & $<\mathrm{LOQ}$ & 208 \\
average & 31.3 & 212.3 & 8.7 & 129.9 \\
sd & 43.9 & 155.5 & 0.6 & 143 \\
min & 7.8 & 59 & 8.2 & 7.8 \\
max & 97 & 370 & 9.1 & 381 \\
\hline
\end{tabular}

LOQ limit of quantification; sd - standard deviation

Sulfonamides are very stable in honey. One year after the ending of treatment of bees, the honey they produce contains sulfonamides in the amount of $1000 \mathrm{ng} / \mathrm{g}$ (Reybroeck et al., 2010). Furthermore, due to their stability, sulfonamides are considered environmental pollutants (Chen and Xie, 2018). Therefore, once contaminated, honey remains an unsafe food until the end of its shelf life.

Examination of honey in the EU imported from third countries showed that $20-50 \%$ of the samples contained residues of antimicrobial drugs, most commonly streptomycin, sulfonamides, tetracyclines and chloramphenicol. However, honey produced in the EU also contained residues of antimicrobial drugs in $1-7 \%$ of the examined samples (Bogdanov, 2006). The results of our research indicate that the contamination of honey residues in Serbia is at the level of the European average. 
In our research it was found that the average concentration of sulfonamides is 10 times higher in honey compared to meat produced in Serbia, and the content of residues in meat is not higher than the maximum residue limits (Kartalović et al, 2020). In farm breeding of cattle, pigs and broilers, sulfonamides are registered drugs and their usage (doses, length of application) is precisely prescribed, so it is possible to meet the withdrawal period deadlines and as a final result the meat that reaches the market is safe in terms of sulfonamide residues. However, sulfonamides are not allowed in beekeeping, so beekeepers use them arbitrarily, probably in very high doses, and as a final outcome, 3.9\% of honey on our market is unsafe only due to the presence of sulfonamides.

\section{PESTICIDES}

Pesticides that can be found in honey usually belong to the group of insecticides used against varroosis (amitraz, coumaphos, etc.). These preparations are applied directly in the hive. However, pesticides that are persistent organic pollutants (POPs) can get into honey as well. Lindane belongs to the group of POPs. It was once used as an insecticide. In addition to the active component, commercial lindane preparations always contain other isomers, mainly $\alpha, \beta$ and $\delta$. After application, lindane mainly accumulates in the soil, and that is how it can reach groundwater and herbs. Due to volatilization and wind erosion, lindane is easily transmitted by air and can reach long distances. Lindane is very stable in the environment (Sandu and Vrista, 2015). Due to its bioaccumulation and toxic effects on human health, lindane has been banned in many countries for decades, but it can still be found in human blood and soil (Mohapatra and Pandey, 2015). In the territory of Vojvodina, lindane was found in soil, wheat and animal tissues (Škrbić 2007; Petrović et al., 2021) but also in imported food (Kartalović et al, 2016). Lindane is often found in wild pigs in Vojvodina (64.6\%), which indicates persistent contamination of the environment and wild animals (Petrović et al., 2021). Lindane reaches honey as a result of environmental contamination. The concentrations in honey are lower than the concentrations found in bees or pollen (Fléché et al. 1997; Schur and Wallner, 2000).

In our research, the average concentration of lindane was determined to be in the range $3-5 \mathrm{ng} / \mathrm{g}$ of acacia, meadow and sunflower honey, while in linden and forest honey the average concentration was lower than $0.5 \mathrm{ng} / \mathrm{g}$. Lindane makes up for $97 \%$ of the total organochlorine pesticide content in acacia honey, $85 \%$ in linden honey, $73 \%$ in meadow and sunflower honey and $58 \%$ in forest honey (Kartalović et al, 2015). In African and Asian countries, the level of lindane in honey is far higher - $14.4 \mathrm{ng} / \mathrm{g}$ Uganda (Mukibii et al., 
2021), $26.9 \mathrm{ng} / \mathrm{g}$ in Pakistan (Rafique et al., 2018), while the content in honey from Serbia is far more similar to the average content in European countries: $3.7 \mathrm{ng} / \mathrm{g}$ in Turkey, $3.87 \mathrm{ng} / \mathrm{g}$ in Italy, $8.5 \mathrm{ng} / \mathrm{g}$ in France (Chauzat et al. 2009; Yavuz et al., 2010; Saitta et al., 2017). The differences in the content are caused by the ban on the use of lindane from different periods. China banned lindane only in 2019 (Mukibii et al., 2021).

Toxicological analyses have shown that consuming honey with a high content of organochlorine pesticides, especially lindane, dieldrin, DDT and endosulfan, can lead to reproductive toxicity: reduced sperm quality, low testosterone levels, reduced testicular weight, abortion (El-Nahhal, 2020). The content of pesticides in honey that can harm human health has been proven in Turkey, Italy (Yavuz et al., 2010; Saitta et al., 2017), India, Pakistan (Rafique et al., 2018), Uganda (Mukibii et al., 2021).

\section{POLYCYCLIC AROMATIC HYDROCARBONS (PAHs)}

PAHs are organic compounds formed during the pyrolysis process (fires, industrial pollution, heating, etc.) (EFSA 2008; Purcaro et al. 2013). PAHs can reach foods during food processing (smoking, grilling) or as a result of environmental pollution (Singh et al. 2016; Mastanjević et al., 2019). Since PAHs have mutagenic and carcinogenic properties, ML (Maximum limits) are prescribed for different types of food. Our legislation is the same as in the EU (Petrović et al., 2019).

PAHs can get into honey in two ways from the environment or during the smoking of hives. PAHs are lipophilic and they most commonly accumulate in a bee itself as they are directly exposed to contamination, they bind more to pollen than to nectar, while the lowest concentrations are in honey (Lambert et al., 2012). During their work, beekeepers often smoke hives and the procedure might be a source of PAHs even though they are found in honey before the hives are smoked (Lambert et al., 2012). A possible source of contamination is an inadequate use of smoke sticks used for treatment against Varroa.

In our research, the presence of all 16 PAHs from the EPA list as hazardous substances was determined in honey (Petrović et al, 2019). Results are presented in Table 2. The average content of 16 PAHs ranged from not detected to $2.35 \mathrm{ng} / \mathrm{g}$, and the highest average concentrations were determined for anthracene. The presence of phenanthrene and anthracene was detected in 90.16 - 95.08\% of the tested samples at concentrations of $1-6 \mathrm{ng} / \mathrm{g}$. Carcinogenic potential of food is determined by the sum of PAH8 (benzo[a]pyrene, chrysene, benz[a]anthracene, benzo[b]fluoranthene, benzo[k]fluoranthene, benzo[ghi] perylene, dibenz $[\mathrm{a}, \mathrm{h}]$ anthracene, indeno[1,2,3-cd]pyrene) or by an individual 
finding of some of them. In our honey tests, $72.1 \%$ of honey samples did not have carcinogenic and genotoxic potential, since PAH $<1 \mu \mathrm{g} / \mathrm{kg}$ was measured in them. In other samples (27.9\%) risky amounts of PAH8 were detected and in four samples of polyfloral honey (6.6\%) extreme values of PAH8 were detected (58.9 -656.2 ng/g PAH8).

Table 2: PAH16 in honey samples (Petrović et al., 2019)

\begin{tabular}{|c|c|c|c|c|c|}
\hline PAH & $\begin{array}{c}\text { Meadow } \\
\mathrm{n}=34\end{array}$ & $\begin{array}{c}\text { Sunflower } \\
n=4\end{array}$ & $\begin{array}{c}\text { Accacia } \\
\mathrm{n}=19\end{array}$ & $\begin{array}{c}\begin{array}{c}\text { Forest } \\
n=4\end{array} \\
\text {. }\end{array}$ & $\begin{array}{l}\text { Total } \\
n=61\end{array}$ \\
\hline \multicolumn{6}{|l|}{ Naphtalene } \\
\hline$<\operatorname{LOD}^{1}(\%)$ & $17(50.00)$ & $4(100.00)$ & $5(26.32)$ & $2(50.00)$ & $28(45.90)$ \\
\hline Min - Max $\mu \mathrm{g} / \mathrm{kg}$ & $0.00-1.25$ & $0.05-0.29$ & $0.06-1.08$ & $0.15-0.90$ & $0.00-1.25$ \\
\hline Median $\pm \mathrm{SD} \mu \mathrm{g} / \mathrm{kg}$ & $0.35 \pm 0.40$ & $0.13 \pm 0.11$ & $0.64 \pm 0.26$ & $0.43 \pm 0.32$ & $0.48 \pm 0.35$ \\
\hline \multicolumn{6}{|l|}{ Acenaphthylene } \\
\hline$<$ LOD (\%) & $26(76.47)$ & $3(75.00)$ & $16(84.21)$ & $2(50.00)$ & $47(78.33)$ \\
\hline $\operatorname{Min}-\operatorname{Max} \mu \mathrm{g} / \mathrm{kg}$ & $0.00-1.59$ & $0.10-2.85$ & $0.04-4.74$ & $0.14-6.24$ & $0.00-6.24$ \\
\hline Median $\pm S D \mu g / k g$ & $0.27 \pm 0.30$ & $0.23 \pm 1.34$ & $0.15 \pm 1.07$ & $2.83 \pm 3.29$ & $0.23 \pm 1.21$ \\
\hline \multicolumn{6}{|l|}{ Acenaphthene } \\
\hline$<\operatorname{LOD}(\%)$ & $14(41.18)$ & $1(25.00)$ & $8(42.11)$ & $1(25.00)$ & $24(40.00)$ \\
\hline $\operatorname{Min}-\operatorname{Max} \mu \mathrm{g} / \mathrm{kg}$ & $0.00-3.39$ & $0.17-15.38$ & $0.09-1.15$ & $0.32-0.94$ & $0.00-15.38$ \\
\hline Median $\pm \mathrm{SD} \mu \mathrm{g} / \mathrm{kg}$ & $0.49 \pm 0.71$ & $0.68 \pm 7.44$ & $0.39 \pm 0.31$ & $0.81 \pm 0.28$ & $0.49 \pm 1.98$ \\
\hline \multicolumn{6}{|l|}{ Fluorene } \\
\hline$<\operatorname{LOD}(\%)$ & $13(38.24)$ & $2(50.00)$ & $6(31.58)$ & $1(25.00)$ & $22(36.67)$ \\
\hline Min - Max $\mu \mathrm{g} / \mathrm{kg}$ & $0.00-0.93$ & $0.05-0.77$ & $0.03-3.22$ & $0.35-2.31$ & $0.00-3.22$ \\
\hline Median \pm SD $\mu \mathrm{g} / \mathrm{kg}$ & $0.44 \pm 0.27$ & $0.53 \pm 0.33$ & $0.45 \pm 0.69$ & $0.56 \pm 0.91$ & $0.45 \pm 0.50$ \\
\hline \multicolumn{6}{|l|}{ Phenanthrene } \\
\hline$<\operatorname{LOD}(\%)$ & $5(14.71)$ & $1(25.00)$ & 0 & 0 & $6(10.00)$ \\
\hline $\operatorname{Min}-\operatorname{Max} \mu \mathrm{g} / \mathrm{kg}$ & $0.00-3.70$ & $0.28-2.14$ & $1.37-3.10$ & $1.39-2.43$ & $0.00-3.70$ \\
\hline Median $\pm S D \mu g / k g$ & $1.97 \pm 0.91$ & $1.61 \pm 0.83$ & $1.91 \pm 0.52$ & $1.83 \pm 0.55$ & $1.93 \pm 0.78$ \\
\hline \multicolumn{6}{|l|}{ Anthracene } \\
\hline$<\operatorname{LOD}(\%)$ & $2(5.88)$ & $1(25.00)$ & 0 & 0 & $3(5.00)$ \\
\hline $\operatorname{Min}-\operatorname{Max} \mu \mathrm{g} / \mathrm{kg}$ & $0.00-6.51$ & $0.22-3.57$ & $1.68-3.42$ & $1.69-2.96$ & $0.00-6.51$ \\
\hline Median $\pm S D \mu g / k g$ & $2.38 \pm 1.20$ & $2.11 \pm 1.43$ & $2.33 \pm 0.58$ & $2.24 \pm 0.67$ & $2.35 \pm 1.02$ \\
\hline \multicolumn{6}{|l|}{ Fluoranthene } \\
\hline$<\operatorname{LOD}(\%)$ & $31(91.18)$ & $4(100.00)$ & $19(100.00)$ & $4(100.00)$ & $58(96.67)$ \\
\hline Min - Max $\mu \mathrm{g} / \mathrm{kg}$ & $0.00-3.61$ & $0.19-0.25$ & $0.01-0.34$ & $0.09-0.23$ & $0.00-3.61$ \\
\hline Median $\pm \mathrm{SD} \mu \mathrm{g} / \mathrm{kg}$ & $0.19 \pm 0.60$ & $0.24 \pm 0.03$ & $0.17 \pm 0.09$ & $0.17 \pm 0.06$ & $0.19 \pm 0.45$ \\
\hline
\end{tabular}




\begin{tabular}{|c|c|c|c|c|c|}
\hline РAH & $\begin{array}{c}\text { Meadow } \\
\mathrm{n}=\mathbf{3 4}\end{array}$ & $\begin{array}{c}\text { Sunflower } \\
\mathrm{n}=4\end{array}$ & $\begin{array}{c}\text { Accacia } \\
\mathrm{n}=19\end{array}$ & $\begin{array}{c}\text { Forest } \\
\mathrm{n}=4\end{array}$ & $\begin{array}{l}\text { Total } \\
\mathrm{n}=61\end{array}$ \\
\hline \multicolumn{6}{|l|}{ Pyrene } \\
\hline < LOD (\%) & $31(91.18)$ & $4(100.00)$ & $19(100.00)$ & $4(100.00)$ & $58(96.67)$ \\
\hline Min - Max $\mu \mathrm{g} / \mathrm{kg}$ & $0.00-3.61$ & $0.19-0.25$ & $0.01-0.34$ & $0.09-0.23$ & $0.00-3.61$ \\
\hline Median \pm SD $\mu \mathrm{g} / \mathrm{kg}$ & $0.19 \pm 0.60$ & $0.24 \pm 0.03$ & $0.17 \pm 0.09$ & $0.17 \pm 0.06$ & $0.19 \pm 0.45$ \\
\hline \multicolumn{6}{|l|}{ Benz $[a]$ anthracene } \\
\hline$<\operatorname{LOD}(\%)$ & $29(85.29)$ & $4(100.00)$ & $19(100.00)$ & $4(100.00)$ & $56(93.33)$ \\
\hline Min - Max $\mu \mathrm{g} / \mathrm{kg}$ & $0.00-87.24$ & $0.19-0.25$ & $0.00-0.12$ & $0.00-0.06$ & $0.00-87.24$ \\
\hline Median \pm SD $\mu \mathrm{g} / \mathrm{kg}$ & $0.00 \pm 15.16$ & $0.24 \pm 0.03$ & $0.00 \pm 0.04$ & $0.00 \pm 0.03$ & $0.00 \pm 11.39$ \\
\hline \multicolumn{6}{|l|}{ Chrysene } \\
\hline$<\operatorname{LOD}(\%)$ & $29(85.29)$ & $4(100.00)$ & $18(94.74)$ & $4(100.00)$ & $55(91.67)$ \\
\hline Min - Max $\mu \mathrm{g} / \mathrm{kg}$ & $0.0-140.58$ & $0.00-0.00$ & $0.00-1.51$ & $0.00-0.32$ & $0.0-140.58$ \\
\hline Median \pm SD $\mu \mathrm{g} / \mathrm{kg}$ & $0.00 \pm 24.38$ & $0.00 \pm 0.00$ & $0.00 \pm 0.39$ & $0.02 \pm 0.16$ & $0.00 \pm 18.30$ \\
\hline \multicolumn{6}{|l|}{$\begin{array}{l}\text { Benzo }[b] \\
\text { fluoranthene }\end{array}$} \\
\hline$<\operatorname{LOD}(\%)$ & $29(85.29)$ & $4(100.00)$ & $19(100.00)$ & $4(100.00)$ & $56(93.33)$ \\
\hline Min - Max $\mu \mathrm{g} / \mathrm{kg}$ & $0.00-23.91$ & $0.00-0.00$ & $0.01-1.99$ & $0.02-0.18$ & $0.00-23.1$ \\
\hline Median \pm SD $\mu \mathrm{g} / \mathrm{kg}$ & $0.11 \pm 4.96$ & $0.00 \pm 0.00$ & $0.07 \pm 0.44$ & $0.13 \pm 0.07$ & $0.19 \pm 0.45$ \\
\hline \multicolumn{6}{|l|}{$\begin{array}{l}\text { Benzo }[k] \\
\text { fluoranthene }\end{array}$} \\
\hline$<\operatorname{LOD}(\%)$ & $29(85.29)$ & $4(100.00)$ & $19(100.00)$ & $4(100.00)$ & $56(93.33)$ \\
\hline Min - Max $\mu \mathrm{g} / \mathrm{kg}$ & $0.00-79.65$ & $0.05-0.13$ & $0.00-2.43$ & $0.01-0.18$ & $0.00-79.65$ \\
\hline Median \pm SD $\mu \mathrm{g} / \mathrm{kg}$ & $0.11 \pm 13.85$ & $0.07 \pm 0.03$ & $0.06 \pm 0.54$ & $0.14 \pm 0.08$ & $0.10 \pm 10.41$ \\
\hline \multicolumn{6}{|l|}{ Benzo[a]pyrene } \\
\hline$<\operatorname{LOD}(\%)$ & $26(76.47)$ & $4(100.00)$ & $19(100.00)$ & $4(100.00)$ & $53(88.33)$ \\
\hline Min - Max $\mu \mathrm{g} / \mathrm{kg}$ & $0.0-120.15$ & $0.05-0.13$ & $0.00-0.12$ & $0.00-0.78$ & $0.0-120.15$ \\
\hline Median \pm SD $\mu \mathrm{g} / \mathrm{kg}$ & $0.09 \pm 20.89$ & $0.07 \pm 0.03$ & $0.00 \pm 0.03$ & $0.04 \pm 0.38$ & $0.04 \pm 15.69$ \\
\hline \multicolumn{6}{|l|}{ Indeno $[c d]$ pyrene } \\
\hline$<\operatorname{LOD}(\%)$ & $28(82.35)$ & $4(100.00)$ & $18(94.74)$ & $4(100.00)$ & $54(90.00)$ \\
\hline Min - Max $\mu \mathrm{g} / \mathrm{kg}$ & $0.00-38.68$ & $0.00-0.04$ & $0.01-4.85$ & $0.03-0.23$ & $0.00-\mathbf{3 8 . 6 8}$ \\
\hline Median \pm SD $\mu \mathrm{g} / \mathrm{kg}$ & $0.07 \pm 8.22$ & $0.00 \pm 0.02$ & $0.03 \pm 1.10$ & $0.06 \pm 0.09$ & $0.06 \pm 6.27$ \\
\hline \multicolumn{6}{|l|}{$\begin{array}{l}\operatorname{Dibenz}[a, h] \\
\text { anthracene }\end{array}$} \\
\hline$<\operatorname{LOD}(\%)$ & $28(82.35)$ & $4(100.00)$ & $18(94.74)$ & $4(100.00)$ & $54(90.00)$ \\
\hline Min - Max $\mu \mathrm{g} / \mathrm{kg}$ & $0.00-39.15$ & $0.01-0.27$ & $0.00-1.86$ & $0.01-0.24$ & $0.00-39.15$ \\
\hline Median \pm SD $\mu \mathrm{g} / \mathrm{kg}$ & $0.06 \pm 7.36$ & $0.05 \pm 0.12$ & $0.03 \pm 0.42$ & $0.05 \pm 0.10$ & $0.05 \pm 5.57$ \\
\hline
\end{tabular}




\begin{tabular}{|c|c|c|c|c|c|}
\hline PAH & $\begin{array}{c}\text { Meadow } \\
\mathrm{n}=34\end{array}$ & $\begin{array}{c}\text { Sunflower } \\
n=4\end{array}$ & $\begin{array}{c}\text { Accacia } \\
n=19\end{array}$ & $\begin{array}{c}\text { Forest } \\
n=4\end{array}$ & $\begin{array}{l}\text { Total } \\
n=61\end{array}$ \\
\hline \multicolumn{6}{|l|}{$\begin{array}{l}\text { Benzo[ghi] } \\
\text { perylene }\end{array}$} \\
\hline$<\operatorname{LOD}(\%)$ & $29(85.29)$ & $4(100.00)$ & $18(94.74)$ & $4(100.00)$ & $55(91.67)$ \\
\hline $\operatorname{Min}-\operatorname{Max} \mu \mathrm{g} / \mathrm{kg}$ & $0.0-136.34$ & $0.01-0.27$ & $0.00-3.65$ & $0.00-0.01$ & $0.0-136.34$ \\
\hline Median \pm SD $\mu \mathrm{g} / \mathrm{kg}$ & $0.02 \pm 23.56$ & $0.24 \pm 0.12$ & $0.00 \pm 0.83$ & $0.00 \pm 0.01$ & $0.02 \pm 17.68$ \\
\hline
\end{tabular}

${ }^{1}$ Limit of the detection

Our research shows that there is a certain risk related to the content of PAHs in honey. It was not possible to define a common PAHs profile for the tested honey samples, which means that there are different sources of contamination. However, the impact of some beekeeping procedures such as smoking and the use of drugs against Varroa have not yet been sufficiently studied and is the subject of future research along with risk assessment for PAHs in honey.

\section{CONCLUSION}

Honey is considered both food and medicine and it is often consumed by the sick and children, and therefore it needs to be absolutely safe for consumption. Our research has confirmed that certain risky substances can be found in honey originating from Serbia. Persistent contaminants such as lindane cannot be eliminated from the environment but further toxicological studies are needed in order to determine whether risky amounts of this pesticide are consumed in the average quantities that people normally take. The content of PAHs that reach honey as a result of environmental pollution (cars, heating, etc.) can be controlled, while further research should determine whether the common methods of hive smoking leave toxic content in honey. And finally, the presence of sulfonamides as a direct result of illegal and irresponsible work of beekeepers poses a significant risk for honey consumption in Serbia. The risk for consumers can be eliminated by educating beekeepers and by introducing strict measures in the trade of antimicrobial drugs.

\section{ACKNOWLEDGEMENT}

This study was funded by Ministry of Education, Science and Technological Development of Republic of Serbia by the Contract of implementation and funding of research work of NIV-NS in 2021, Contract No: 451-03-9/202114/200031 and was also supported by Provincial Secretariat for Agricul- 
ture, Water Management and Forestry of Vojvodina, Contract No: 104-401$4672 / 2021 / 01$.

\section{Author's Contribution}

This paper was written as a review paper which dealt with a series of papers in the field of honey safety. All authors of this paper have participated in the writing of this paper and previous research. Writing papers JP and JPR, examinations BK and JV, and data processing RR and IS.

\section{Competing interest}

The authors declare that they have no competing interests.

\section{REFERENCES}

1. Babić J., Ljubojević D., Vidaković S., Žekić-Stošić M., Kartalović B., Petrović J., Plavša N. 2017. Honey as bioindicator of environmental contamination. Ecologica, 2, 24, 88, 838-840.

2. Barganska Z., Slebioda M., Namiesnik J. 2011. Determination of antibiotic residues in honey. Trends in Analytical Chemistry, 30,7,:1035-1041.doi: 10.1016/j.trac.2011.02.014.

3. Bogdanov S. 2006. Contaminants of bee products. Apidologie, 37,1-18. doi: 10.1051/apido:2005043.

4. Chauzat M.P., Carpentier P., Martel A.C., Bougeard S., Cougoule N., Porta P., Lachaize J., Madec F., Aubert M., Faucon J.P. 2009. Influence of pesticide residues on honey bee (Hymenoptera: Apidae) colony health in France Environ. Entomology, 38, 3, 514-523. doi: 10.1603/022.038.0302.

5. Chen J. and Xie S. 2018. Overview of sulfonamide biodegradation and the relevant pathways and microorganisms. Science of the Total Environment, 640-641, 1465-1477. doi: 10.1016/j.scitotenv.2018.06.016.

6. Cook N.C. and Sammon S. 1996. Flavonoids: chemistry, metabolism, cardioprotective effects, and dietary sources. The Journal of Nutritional Biochemistry, 7,2, 66-76. doi: 10.1016/S0955-2863(95)00168-9.

7. EFSA - European Food Safety Authority 2008. Polycyclic Aromatic Hydrocarbons in Food. Scientific Opinion of the Panel on Contaminants in the Food Chain. The EFSA Journal, 724, 1-114.

8. El-Nahhal Y. 2020. Pesticide residues in honey and their potential reproductive toxicity. Science Total Environment, 741, 139953. doi:10.1016/j. scitotenv.2020.139953. 
9. Fléché, C., Clément, M., Zeggane, S., Faucon, J. 1997. Contamination des produits de la ruche et risques pour la santé humaine: situation en France. Revue Scientifique et Technique (International Office of Epizootics), 16, 2, 609-619.

10. Kartalović B., Babić J., Prica N., Živkov-Baloš M., Jakšić S., Mihaljev Z., Ćirković M. 2015. The preence of lindane in different types of honey in the Panonian region. Bulgarion journal of Agricultural Science, 21, 1, 208-212.

11. Kartalović B., Novakov N., Mihaljev Ž., Petrovićć J., Prica N., Babić J., Ćirković M. 2016. Organochlorine pesticides in canned tuna and sardines on the Serbian market. Food Additives and Contaminants: Part B , 9, 4, 299304. doi: 10.1080/19393210.2016.1234004.

12. Kartalović B., Petrović J., Ratajac R., Vidaković S., Stojanović D., Mirčeta J., Đorđević V. 2020. Survey of sulfonamides in meat and honey in Vojvodina market, Serbia. Journal of Food Safety and Food Quality 71, 1, 10-15. doi: 10.2376/0003-925X-71-10.

13. Lambert O., Veyrand B., Durand D., Marchand P., Le Bizec B., Piroux M., Puyo S., Thorin C., Delbac F., Pouliquen H. 2012. Polycyclic aromatic hydrocarbons: Bees, honey and pollen as sentinels for environmental chemical contaminants. Chemosphere, 86, 98-104. doi: 10.1016/j.chemosphere.2011.09.025.

14. Maroubo L., Pedrina W, Melchert W. 2021. Total sulfonamides determination in bovine milk using smartphone-based digital images. Microchemical Journal, 170, 106657, doi.org/10.1016/j.microc.2021.106657.

15. Mastanjević K., Kartalović B., Lukinac J., Jukic M., Kovačević D., Petrović J., Habschied K. 2019. Distribution of 16 polycyclic aromatic hydrocarbons (PAHs) in traditional dry cured smoked ham Slavonska šunka. Applied Sciences, 10, 90, 1-7. doi: 10.3390/app10010092.

16. Mohapatra S., Pandey M. 2015. Biodegradation of Hexachlorocyclohexane (HCH) Isomers by White Rot Fungus, Pleurotus florida. Journal of Bioremedation and Biodegradation, 6, 280. doi:10.4172/2155-6199.1000280.

17. Mukibii S., Nyanzia S.A., Kwetegyekab J., Olisah C., Taiwo A.M., Mubiru E., Tebandeke E. 2021. Organochlorine pesticide residues in Uganda's honey as a bioindicator of environmental contamination and reproductive health implications to consumers. Ecotoxicology and Environmental Safety, 214, doi:10.1016/j.ecoenv.2021.112094.

18. Petrović J., Kartalović B., Mirčeta J., Prodanov-Radulović J., Ratajac R., Mastanjević K. 2021. Organochlorine pesticides and NDL-PCBs in wild boars from flatland region with intensive agricultural activities. Food additives \& contaminants: part B doi:10.1080/19393210.2021.1976287. 
19. Petrović J., KartalovićB., Ratajac R., Spirić D., Djurdjević B., Polaček V., Pucarević M. 2019 PAHs in different honeys from Serbia, Food Additives \& Contaminants: Part B doi.:10.1080/19393210.2019.1569727.

20. Plavša N., Stojanov I., Milanov D., Petrović J. 2008. American foulbrood epizootilogical situation and the importance of early detecting. Archives of Veterinary Medicine, 1, 2, 41-49.

21. Purcaro G., Moret S., Conte L.S. 2013. Overview on polycyclic aromatic hydrocar-bons: occurrence legislation and innovative determination in foods. Talanta, 105, 292-305. doi: 10.1016/j.talanta.2012.10.041.

22. Rafique N., Nazir S., Akram S., Ahad K., Gohar A., Abbasi S.T., Ahmed I., Rafique K. 2018. Screening of multiclass pesticide residues in honey by SPE-GC/MSD: a pilot study. Environmental Monitoring and Assessment, 190, 11, 666, doi: 10.1007/s10661-018-7041-4.

23. Reybroeck W., Daeseleire E., De Brabander H..F, Herman L. 2012. Antimicrobials in beekeeping. Veterinary Microbiology, 158,1-11. doi: 10.1016/j.vetmic.2012.01.012.

24. Reybroeck W., Jacobs F.J., De Brabander H.F., Daeseleire E. 2010. Transfer of Sulfamethazine from Contaminated Beeswax to Honey. Journal of Agriculture and Food Chemistry, 58, 7258-7265. doi: 10.1021/jf1005275.

25. Saitta M., Di Bella G., Fede M.R., Lourco V., Potortì A.G., Rando R., Russo M.T., Dugo G. 2017. Gas chromatography-tandem mass spectrometry multi-residual analysis of contaminants in Italian honey samples. Food Additives and Contaminants Part A, 34, 5, 800-808. doi: 10.1080/19440049.2017.1292054.

26. Sandu M.A., Virsta A. 2015. Environmental toxicity of lindane and health efect. Journal of Environmental Protection and Ecology 16, 3, 933-944.

27. Schur, A. and Wallner, K. 2000. Bewertung des individuellen Wirkstoffeintrages von Sammelbienen nach Pestizidapplikation in bluhende Kulturen. Apidologie, 31, 615-616.

28. Singh L., Varshney J., Agarwal T. 2016. Polycyclic aromatic hydrocarbons' formation and occurrence in processed food. Food Chemistry, 199, 768781. doi: 10.1016/j.foodchem.2015.12.074.

29. Škrbić B. 2007. Organochlorine and organophosphate pesticide residues in wheat varieties from Serbia, Food Additives \& Contaminants, 24:7, 695703. doi: 10.1080/02652030601182888.

30. Solomon J.R.D., Santhi S.V., Jayaraj V. 2006. Prevalence of Antibiotics in Nectar and Honey in South Thamilnadu, India. Integrative Biosciences, 10,3,163-167.doi: 10.1080/17386357.2006.9647297. 
31. Wei G., Huang J., Yang J. 2012. Honey Safety Standards and Its Impacts on China's Honey Export. Journal of Integrative Agriculture, 11,4, 684-693. doi: 10.1016/S2095-3119(12)60056-2.

32. Yavuz H., Guler G.O., Aktumsek A., Cakmak Y.S., Ozparlak H. 2010. Determination of some organochlorine pesticide residues in honeys from Konya, Turkey. Environmental Monitoring Assessment, 168, 1-4, 277-283. doi: 10.1007/s10661-009-1111-6.

Received: 24.11.2021.

Accepted: 16.12.2021. 